\author{
Paweł Stelmach \\ University of Physical Education in Kraków \\ Faculty of Tourism and Recreation \\ Chair of Tourism Policy \\ Economics and Management Department \\ pawel.stelmach@awf.krakow.pl
}

\title{
SPA SERVICES DISTRIBUTION AND SPECIALIZATION IN KUJAWSKO-POMORSKIE, POMORSKIE AND PODKARPACKIE VOIVODESHIPS COMMUNES
}

\begin{abstract}
The objective of the article is to identify and explain the relationship between spa services distribution and spa specialization in Kujawsko-Pomorskie, Pomorskie and Podkarpackie Voivodeships spa communes. Correlation and regression analysis were used based on data from the Local Data Bank and unpublished data sets from the Central Statistical Office of Poland. In order to explain the relation between spa services distribution and spa specialization, time-series analysis was used. In five of nine researched communes (Horyniec-Zdrój, Solina, Ustka, Ciechocinek and Inowrocław) there is a functional relationship between spa services distribution and spa specialization.
\end{abstract}

Keywords: spa specialization, tourism specialization, spa, distribution, spa resort.

\section{INTRODUCTION}

The chosen research issue is the verification of the relationship between the spa services distribution and spa specialization in the Kujawsko-Pomorskie, Pomorskie and Podkarpackie Voivodeships. The aim is to identify and explain these relation. The following question was asked: if, and if so - to what extent, there is a correlation or functional relationship between spa services distribution and spa specialization in the communes analyzed.

The scope of the analysis, in relation to a pilot study (STELMACH 2017a) where only Podkarpackie spas, focused mainly on mountain foothills were considered, has been widened. Therefore, lowland spa communes from the Kujawsko-Pomorskie and Pomorskie Voivodeships have been included in the current study. Thus, the scope has been extended to approximately $23 \%$ of total spa inpatients in Poland and to $22 \%$ of commercial spa inpatients (mainly due to the inclusion of Ciechocinek). In total, these communes in 2015 served 29\% of all spa inpatient in Poland and $29 \%$ of commercial spa inpatient (according to unpublished data provided by the Statistical Office in Kraków).

The article presents the results of research on the relationship between the distribution of spa services and spa specialization in the communes of Kujawsko-
Pomorskie, Pomorskie and Podkarpackie. In spa towns, spa services are distributed in two complementary channels: market (commercial) and state (social). Their relative proportions may be related to spa specialization, and a specific tourism specialization of spa com-munes which play a special role in their economy (SZROMEK 2012a, b, 2015).

Distribution is based on the availability and accessibility of products for customer purchase (ROMANOVA et al. 2015). The distribution of spa services to spa patients is carried out using two indicated channels. They differ in the source of funding and the type of patient. Spa services distribution is the way they are purchased by the consumer from the supplier (sanatorium or spa hospital).

Within the social channel, the state subsidizes spa services in the form of indirectly distributed benefits. The intermediaries are usually public insurers: health (the National Health Fund - NFZ) and social (the Polish Social Insurance Institution - ZUS, and the Agricultural Social Insurance Fund - KRUS), as well as other bodies (especially the State Fund for Rehabilitation of Persons with Disabilities - PFRON). The recipients of this channel are the so-called non-private spa patients who are covered by sickness insurance or 
social insurance, and other eligible persons. Appropriate medical documentation is required when applying for this type of state funded financial support.

In turn, the market channel is characterized through the financing of spa services by the so-called commercial (self-paying) spa patient. The other aspect of the market channel is direct distribution where the consumer buys services from the supplier itself.

Spa specialization is the part of tourism specialization, understood as an element of the economic structure of an area (ZMYŚLONY 2015) or as an economic function of a tourist destination (MAJEWSKA 2012, GOŁEMBSKI \& MAJEWSKA 2015). The tourism specialization is thus a part of tourism in the economy.

Compared to better-explored tourism specializations (DURYDIWKA 2012, MAJEWSKA 2012, SZROMEK 2012b, KOSMACZEWSKA 2013, GOŁEMBSKI \& MAJEWSKA 2015, ZMYŚLONY 2015), spa specialization has sso far appeared as a relatively modest but developing and interesting research area. It is understood as a specific specialization of spa communes playing a special role in their economy (SZROMEK 2012a, b 2015). The spa specialization is considered to be one of the essential functions of this tourism destination (SZROMEK 2015) which integrates both tourist and therapeutic activities as well as social and economic goals. At the same time, it is a socio-economic action aimed at the healing of patients which the spa commune simultaneously achieves for the national economy and the health care system (SZROMEK 2012a).

In this light, taking into account the operationalization of the spa specialization in STELMACH's (2017a) study, a spa is understood as a part of the spa economy within the tourism economy. A method of measuring spa specialization has already been worked out determining what proportion of overnight stays in a spa destination are in spa establishments (sanatoria and spa hospitals). Such an estimate allows the basic tourism specialization in spa communes to be assessed.

Tourism destinations differ from each other in terms of the level, structure and dynamics of their tourism specialization. Spa communes, which are a special form of tourism destination, usually target their activities on spa healing therapies (as in BuskoZdrój, Horyniec-Zdrój, Iwonicz-Zdrój, RymanowZdrój), but sometimes the main spa commune customers are tourists who are not spa inpatients (Solec-Zdrój, Solina) (STELMACH 2017b, SZROMEK 2015).

The paper is organized as follows: a literature review introduces the current status of research, a method and data sources section provides the particular research aims, research techniques and data origins used for analyzing the research issue; the results section presents research findings; while the last section concludes the paper and suggests further directions and policy implications.

\section{LITERATURE REVIEW}

The relationship between spa service distribution and the development of a spa and tourism specialization has not been academically explored until now. An exception is a study by STELMACH (2017a) where the association was analysed for Podkarpackie spa communes (in 2015 they accounted for 7\% of total spa inpatients in Poland and $4 \%$ of private spa inpatients - according to an unpublished data set provided by the Statistical Office in Kraków). The research conducted so far has to a small extent considered spa services distribution, and the spa and tourism specialization of communes, usually analyzing these issues separately.

Research on service distribution has focused on the duality and diversification of distribution channel (ROMANOVA et al. 2015, SZROMEK et al. 2016, DRYGLAS \& RÓŻYCKI 2016, 2017, DRYGLAS \& SALAMAGA 2017, STELMACH 2017a, b) and its consequences for spa companies and communes (DERCO \& PAVLISINOVA 2016, DRYGLAS \& RÓŻYCKI 2016, 2017, DRYGLAS \& SALAMAGA 2016, SZROMEK et al. 2016, VRKLJAN \& HENDIJA 2016). Existing research in these two areas has produced the following conclusions (STELMACH 2017a):

1) The current excessive dependence of spas in some communes on the state distribution channel is risky, as sudden legal or financial regulatory shocks can pose an economic threat to spa companies and communes. Moreover, non-commercial spa patients bring less income to both spa companies and communes.

2) Commercial spa patients are key customers because they provide greater value for spa companies and destinations in the form of higher spending and more valuable feedback. For some spa communes, foreign spa patients are the key guests. The ability to attract a commercial spa patient is a strategic challenge for spa communes and may have an impact on their further development.

However, there were no studies identifying the effects that spa services distribution could have on the development of spa or tourist specializations. Neither has there been an analysis of whether the level of spa or tourism specialization of a commune could influence spa service distribution.

The analysis of the relationship between spa service distribution and the development of a spa specialization is therefore a new area of research. It has been established (STELMACH 2017a) that a total of 34 Polish spa communes treated jointly ${ }^{1}$, representing $79 \%$ of spa communes in Poland ${ }^{2}$, have a strong relation (Spearman correlation coefficient of -0.9), a statistically significant negative correlation between spa services distribution (measured as the share of the number of commercial spa patients from the total 
number), and spa specialization (measured as the share of the number of nights spent in spa establishments from the total number). However, in that study, limited assumptions were made about the interpretation of this result, leading to a deeper analysis. In particular, it would be advisable to analyse a time series of correlated indicators.

On the other hand it was stated that in Podkarpackie Voivodeship there are communes, such as Horyniec-Zdrój, where the correlation is strong, statistically significant and positive, whereas for the other Podkarpackie communes the correlations turned out to be statistically insignificant, negative and weak, or average. Thus, it was found that in some communes the relationship in question was stronger, while in others - significantly weaker. This diversity also deserves further analysis and explanation.

There was also no verification whether, in the situation where the relationship was identified, it had a functional character. The hypothetical dependent variable would be spa specialization in such cases, while spa service distribution would be treated as an independent variable. It is also possible to consider the legitimacy of analyzing the reverse relationship, i.e. if spa service distribution depends on spa specialization. Both perspectives can deepen the understanding of spa destination management.

\section{METHOD AND DATA SOURCES}

Table 1 shows the research procedure and the ordered set of research techniques and sources comprising the method.

Quantitative techniques were used to accomplish the research goals and answer research questions. Time-series analysis serves to improve an understanding of the variability of correlations and to identify their properties such as trends, seasonality and structural breaks. Spearman correlation analysis with a Student $t$-tests is used to identify statistically significant relationships between variables with asymmetric distribution and the small number of available observations. Simple regression analysis models the relationships between the dependent variable (which hypothetically represents spa specialization) and the independent variable (spa service distribution). However, in order to verify this supposition, the relationship was modelled using regression analysis in a reverse order of variables, i.e. spa service distribution as a dependent variable and spa specialization as an independent variable.

The scope of research included 43 Polish spa communes, 34 of which were identified as having available data for correlation and regression analysis for 2005-14. The spatial extent of the research included three spa communes of Kujawsko-Pomorskie Voivodeship (Ciechocinek, Inowrocław, Brześć Kujawski), two from Pomorskie (Ustka, Sopot) and four from Podkarpackie (Horyniec-Zdrój, Iwonicz-Zdrój, Rymanów, Solina).

The relatively small number of observations $(N=$ $10,2005-14)$ was not in this case due to a lack of attention to the maximum extent of the time-series data period, but because of the length of time the Central Statistical Office has collected statistics on the number of commercial spa inpatients (data available from 2005) and the coming into force of an amendment to the Public Statistics Act of 2015, which resulted in the Central Statistical Office ceasing access to data on the number of overnight stays at commune level from 2015.

In order to measure the theoretical constructs used in the study, the concepts of spa service distribution and spa specialization were operationalized. As in P. STELMACH'S (2017a) work, spa service distribution was measured by:

$\begin{gathered}\text { Spa service } \\ \begin{array}{c}\text { distribution } \\ \text { indicator }\end{array}\end{gathered}=\frac{\text { Self-pay spa inpatient number }}{\text { Total spa inpatient number }}$,

where inpatient means a patient using treatment on a 24 -hour or on a daytime basis, i.e. in a sanatorium or spa resort hospital.

For reasons given in P. STELMACH (2017a) spa specialization was measured using:

$$
\begin{gathered}
\text { Spa } \\
\begin{array}{c}
\text { specialization } \\
\text { indicator }
\end{array}
\end{gathered}=\frac{\text { Nights spent in spa establishments }}{\text { Total nights spent in tourist accommodation establishments }}
$$

where a spa establishment is a health care provider located in a spa commune and uses natural healing resources in the provision of health services.

The main research material was secondary Central Statistical Office data from two areas of official statistics: tourism (form KT-1) and health (form ZD-2). Public tourism statistics are incomplete because they include only registered accommodation establishments (WŁODARCZYK 2017, SZAFRAŃSKA et al. 2015), omitting provision by family, friends, second homes, private accommodation, etc., and lodgings in the informal sector, i.e. those not reported in the official statistics by registered accommodation establishments and that provided by bodies conducting illegal business activities.

On the other hand, it should be noted that although primary research gives more accurate results than secondary research, nonetheless, in the absence of existing primary research (as here) they can be preceded by an analysis of secondary data. Public statistics are the basis for the study of tourism phenomena and 
Table 1. Research method

\begin{tabular}{|l|l|l|}
\hline \multicolumn{1}{|c|}{ Purpose of research } & \multicolumn{1}{|c|}{ Data sources } & \multicolumn{1}{c|}{ Research techniques } \\
\hline $\begin{array}{l}\text { Identification of time series } \\
\text { for spa service distribution }\end{array}$ & $\begin{array}{l}\text { Secondary data concerning 43 Polish spa communes } \\
\text { from 2005 to 2015, originating from an unpublished } \\
\text { data set from the Central Statistical Office from the } \\
\text { Statistical Office in Kraków. }\end{array}$ & Time series analysis \\
\hline $\begin{array}{l}\text { Identification of a time series } \\
\text { for spa specialization }\end{array}$ & $\begin{array}{l}\text { Secondary data concerning 43 Polish spa communes } \\
\text { from 1995-2014 from the Central Statistical Office Local } \\
\text { Data Bank. }\end{array}$ & \multicolumn{1}{|c|}{$\begin{array}{l}\text { 1. Analysis of Spearman rank } \\
\text { correlation }\end{array}$} \\
\hline $\begin{array}{l}\text { Estimation of the correlation } \\
\text { and dependence between spa } \\
\text { service distribution and spa } \\
\text { specialization }\end{array}$ & $\begin{array}{l}\text { Secondary data concerning 34 spa communes from } \\
\text { 2005-14 from the Central Statistical Office unpublished statistical } \\
\text { data and Local Data Bank. }\end{array}$ & $\begin{array}{l}\text { significance of correlation } \\
\text { coefficients } \\
\text { 3. Regression analysis }\end{array}$ \\
\hline
\end{tabular}

Source: author.

provide a reference point for the design of primary research (DZIEDZIC 2010), for the purpose of determining a sampling frame (BORKOWSKI et al. 2017) and sample structure (WŁODARCZYK, ed. 2017), at the same time being the basis of statistical estimates of tourists number. In addition, Central Statistical Office data has the value of continuity and relative methodological uniformity, which much primary research does not have making it use-less for the purpose of identifying relationships over time. In this state of affairs the use of secondary data should be considered justified.

\section{RESULTS}

According to the procedural sequence described in Table 1 the identified time series for the distribution of spa services are presented on Fig. 1.

In Fig. 1, a common pattern of growth in the share of self-paying spa patients from the total number of spa patients in the communes analyzed can be seen. It is pro-cyclical, i.e. consistent with economic cycles, which is evident especially in relation to the series of data referring to the 34 spa communes. The aboveaverage share of private patients, especially in the communes of Horyniec-Zdrój and Ciechocinek. In 2014, the spa service distribution was close to the national average in Inowroclaw and Sopot. On the other hand, a very low proportion of commercial patients is found in Wieniec-Zdrój and Polańczyk-Zdrój.

In turn, the identified time series for spa specialization is shown on Fig. 2.

In Fig. 2 the number of overnight stays in Kujawsko-Pomorskie and Podkarpackie spa communes (with the exception of Solina) vis-à-vis Pomorskie communes

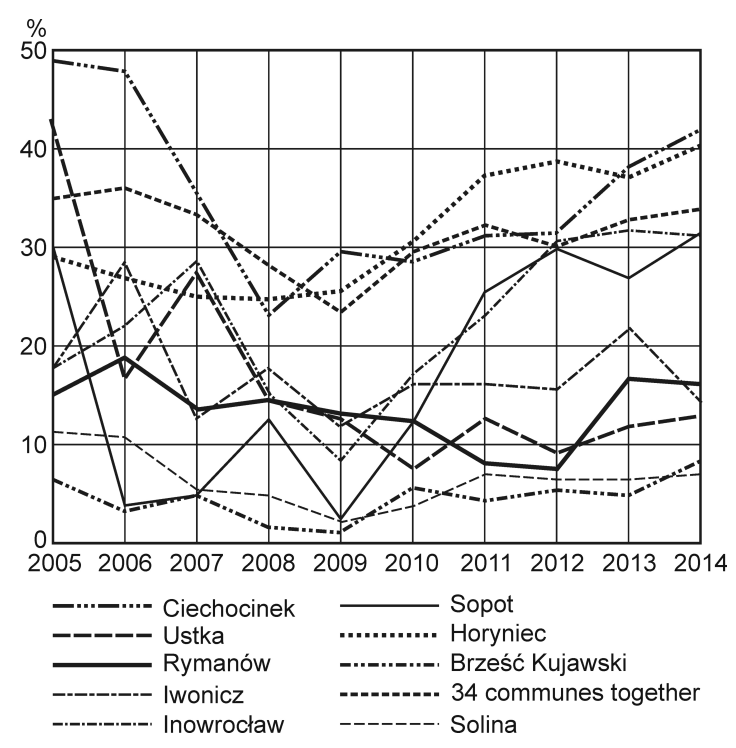

Fig. 1. Dynamics of spa service distribution in communes from Kujawsko-Pomorskie, Pomorskie and Podkarpackie Voivodeships: 2005-14

Source: author, based on unpublished data from Central Statistical Office acquired from the Statistical Office in Kraków

is noticeable. Kujawsko-Pomorskie and most of the Podkarpackie spa communes are distinguished by a concentration of overnight stays in spa establishments, while in Pomorskie and in Solina lodging outside spa establishments predominates. The pattern of variation in the spa specialization indicator for the 34 communes is countercyclical, i.e. it negatively correlates with periods of economic growth. It is also a reversal of the variation in the indicator for spa service distribution in Fig. 1. This is a partial explanation of the strong negative correlation identified in P. STELMACH'S study (2017a), also referred to in Table 2, 
Table 2. Spearman's correlation coefficients between spa service distribution and spa specialization: 2005-14

\begin{tabular}{|c|c|c|c|c|c|}
\hline Brześć Kujawski & Ciechocinek & Inowrocław & Sopot & Ustka & \multirow{2}{*}{$\begin{array}{c}\text { The critical value of the correlation } \\
\text { coefficient for } N=10 \text { and } p=0.05 \\
\text { (two-sided critical area) }\end{array}$} \\
\hline 0.3 & -0.28 & 0.61 & -0.44 & -0.75 & \\
\hline Horyniec-Zdrój & Iwonicz-Zdrój & Rymanów & Solina & 34 communes & \multirow{2}{*}{0.65} \\
\hline 0.88 & -0.21 & -0.28 & -0.48 & -0.9 & \\
\hline
\end{tabular}

Source: author, based on Central Statistical Office Local Data Bank and unpublished data from the Statistical Office in Kraków.

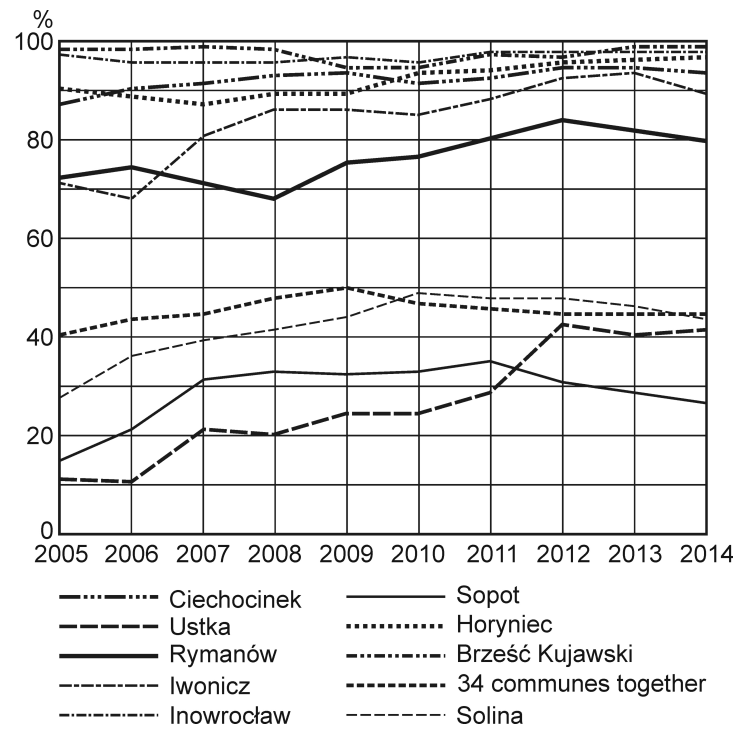

Fig. 2. Changes in spa specialization in Kujawsko-Pomorskie, Pomorskie and Podkarpackie Voivdeship communes: 2005-14 Source: author, based on Central Statistical Office Local Data Bank

showing figures for the correlation of the indicators illustrated on Fig. 1 and 2.

A strong and statistically significant negative correlation between the distribution of spa services and spa specialization was found for Ustka. For HoryniecZdrój, the correlation analyzed is strong, statistically significant and positive, whereas for Inowrocław there was a strong correlation coefficient, which was slightly lower than the threshold of statistical significance. For the other communes the correlations were statistically insignificant and average (Sopot and Solina), or weak (Brześć Kujawski, Ciechocinek, Iwonicz-Zdrój and Rymanów). There was a domination of negative correlations (in six communes) over positive (in three). It should be noted that in the case of a small number of observations - as in the current study - it is more difficult to confirm the statistical significance of the correlation coefficient, and to achieve this it is needed to identify a high-power correlation.

Spearman's correlation coefficients, usually but not always, suggest the possibility of a functional relationship of similar power and statistical significance. However, it was decided to check, whether this was the case by modelling the variables with a simple linear regression analysis using the ordinary least squares method (the Gretl econometric program). In order to determine the correctness of the model specification, in particular the choice of the dependent variable, models were compared with those of the reverse as an relationships, i.e. the first model for spa specialization as a dependent variable and spa service distribution independent were compared in each case with a second model where spa service distribution was the dependent variable and the spa specialization the independent. For most estimates, the first model was better, i.e. has the lower Akaike information criterion. The results of these models is shown in Table 3.

Table 3. Ordinary least squares estimation for the spa specialization dependent variable and spa service distribution independent variable

\begin{tabular}{|c|c|c|c|c|c|}
\hline Area & \multicolumn{2}{|c|}{ Coefficient } & \multirow{2}{*}{$\begin{array}{c}p \\
p \\
\text { value }\end{array}$} & \multirow{3}{*}{$\begin{array}{c}R^{2} \\
\mathbf{0 . 8 1}\end{array}$} & \multirow{3}{*}{$\begin{array}{c}\begin{array}{c}\text { Akaike } \\
\text { infor- } \\
\text { mation } \\
\text { criterion }\end{array} \\
-59\end{array}$} \\
\hline \multirow{2}{*}{$\begin{array}{l}34 \text { communes } \\
\text { together }\end{array}$} & intercept & 0.64 & & & \\
\hline & distribution & -0.61 & 0.0004 & & \\
\hline \multirow{2}{*}{$\begin{array}{l}\text { Horyniec- } \\
\text { Zdrój }\end{array}$} & intercept & 0.74 & $<0.0001$ & \multirow{2}{*}{0.89} & \multirow{2}{*}{-57} \\
\hline & distribution & 0.57 & $<0.0001$ & & \\
\hline \multirow{2}{*}{ Ciechocinek } & intercept & 0.97 & $<0.0001$ & \multirow{2}{*}{0.32} & \multirow{2}{*}{-48} \\
\hline & distribution & -0.15 & 0.091 & & \\
\hline \multirow{2}{*}{ Inowrocław } & intercept & 0.96 & $<0.0001$ & \multirow{2}{*}{0.31} & \multirow{2}{*}{-70} \\
\hline & distribution & 0.05 & 0.0932 & & \\
\hline \multirow{2}{*}{\begin{tabular}{|l|} 
Brześć \\
Kujawski \\
\end{tabular}} & intercept & 0.97 & $<0.0001$ & \multirow{2}{*}{0.14} & \multirow{2}{*}{-56} \\
\hline & distribution & 0.24 & 0.28 & & \\
\hline \multirow{2}{*}{ Sopot } & intercept & 0.31 & $<0.0001$ & \multirow{2}{*}{0.07} & \multirow{2}{*}{-2} \\
\hline & distribution & -0.14 & 0.45 & & \\
\hline
\end{tabular}

Source: author

In the lesser cases, the second model was characterized by a better Akaike information criterion. The parameters of these models are described in Table 4.

Verification of the statistical significance of the explanatory variable, with a level $\alpha=0.1$, was based on the hypotheses:

$\mathrm{H}_{0}$ : independent variable significantly influences the dependent variable, 
$\mathrm{H}_{1}$ : independent variable does not significantly affect the dependent variable.

Table 4. Ordinary least squares estimation for a spa service distribution dependent variable and spa specialization independent variable

\begin{tabular}{|c|c|c|c|c|c|}
\hline Area & \multicolumn{2}{|c|}{ Coefficient } & $p$ value & $R^{2}$ & $\begin{array}{c}\text { Akaike } \\
\text { information }\end{array}$ \\
\hline \multirow[b]{2}{*}{ Solina } & intercept & 0.52 & $<0.0001$ & \multirow[b]{2}{*}{0.49} & \multirow[b]{2}{*}{-46} \\
\hline & $\begin{array}{c}\text { spa } \\
\text { specialization } \\
\end{array}$ & -1.61 & 0.0244 & & \\
\hline \multirow[b]{2}{*}{ Ustka } & intercept & 0.37 & 0.0003 & \multirow[b]{2}{*}{0.36} & \multirow[b]{2}{*}{-18} \\
\hline & \begin{tabular}{|c|} 
spa \\
specialization \\
\end{tabular} & -0.65 & 0.065 & & \\
\hline \multirow{2}{*}{$\begin{array}{l}\text { Iwonicz- } \\
\text { Zdrój }\end{array}$} & intercept & 0.98 & $<0.0001$ & \multirow[b]{2}{*}{0.21} & \multirow[b]{2}{*}{-32} \\
\hline & \begin{tabular}{|c|} 
spa \\
specialization \\
\end{tabular} & -0.81 & 0.19 & & \\
\hline \multirow[b]{2}{*}{ Rymanów } & intercept & 0.84 & $<0.0001$ & \multirow[b]{2}{*}{0.16} & \multirow[b]{2}{*}{-37} \\
\hline & $\begin{array}{c}\text { spa } \\
\text { specialization } \\
\end{array}$ & -0.57 & 0.2472 & & \\
\hline
\end{tabular}

Source: author.

As Table 3 shows, the well-matched and statistically significant dependence of spa specialization on spa service distribution for the 34 communes, HoryniecZdrój and Solina in particular were moderately matched while statistically significant relationships for Ustka (Table 4) and Inowroclaw were also obtained. Somewhat surprising is the functional relationship for Ciechocinek, in the light of the weak correlation earlier identified (Table 2). For Iwonicz-Zdrój, Rymanów, Brześć Kujawski and Sopot, however, dependencies proved to be unmatched and statistically insignificant. Thus, it has been established that the analysed relationship in some spa communes is stronger, while in others it is significantly weaker. However, clarification of this differentiation requires further research.

On the basis of the analysis in Figs 1 and 2, one of the reasons for the negative dependence of spa specialization on spa service distribution for the 34 communes is the countercyclical spa specialization and the symmetrically pro-cyclical spa service distribution.

In turn, by verifying the earlier assumption (STEL$\mathrm{MACH} 2017 \mathrm{a}$ ), it should be noted that for the majority of spa communes for which the relationships concerned are statistically significant, spa specialization is negatively related to spa service distribution. In three spa communes (Ciechocinek, Ustka and Solina) extensively developing the spa specialization reduces the proportion of the market distribution channel, deepening the dependence on the state distribution channel. In Ciechocinek spa specialization depends on spa service distribution, while in Solina and Ustka spa service distribution depends on spa specialization. In the second group of spa communes (Horyniec-Zdrój and Inowrocław) the increase in spa specialization depends on the increasing proportion of commercial distribution. So far analysis has revealed the existence of two different development patterns for spa communes in which there is a link between spa specialization and spa service distribution.

\section{CONCLUSIONS}

The research made it possible to answer the research question posed. For nine analyzed spa communes from Kujawsko-Pomorskie, Pomorskie and Podkarpackie Voivodeships:

1. In three communes spa service distribution has a significant influence on spa specialization.

2. In two communes spa specialization has a significant influence on spa service distribution.

3. In four communes spa specialization and spa service distribution do not affect each other.

In addition, it was found that the presumed explanation for the negative dependence of spa specialization on spa service distribution for the 34 Polish communes analyzed is the countercyclical spa specialization and the symmetrically pro-cyclical spa service distribution.

The existence of two different development patterns for spas has been identified where there is a link between spa specialization and spa service distribution:

1. Extensive development of spa specialization based on an increase in the share of non-commercial patients.

2. Intensive rise of spa specialization depends on an increasing share of the private distribution type.

These different developmental patterns can have an impact on the balance of benefits and costs concerning spa communes serving the spa and other tourists in particular areas. Thus, it becomes clear that the chosen direction of research is important for spa communes whose authorities manage the spa specialization as a tourism specialization of special importance which they implement in cooperation with spa treatment companies, applying a certain spa service distribution, and other companies meeting the spa's visitor needs.

Taking into consideration that entrepreneurs serving spa destination visitors are often interested in maximizing profits by maximizing revenues, the question that follows is: What is the dependence of spa revenue on the identified development profiles of spa communes? It also seems worth considering whether 
the economic success of a spa destination depends on the share of non-commercial spa patients in the total number of tourists. In other words, it is to empirically assess the influence of visitors on the economic benefits of the destination, especially since this differs in each spa commune, with different scales and directions between the indicators concerned. The research may continue in the future to be the basis for a selection of socio-economic development strategies in spa communes.

\section{ENDNOTES}

${ }^{1}$ These are the health resort communities: Augustów (urban commune), Brześć Kujawski (Wieniec-Zdrój), Busko-Zdrój, Ciechocinek, Darłowo (Dąbki), Duszniki-Zdrój, Goczalkowice-Zdrój, Gołdap, Horyniec-Zdrój, Inowrocław, Iwonicz-Zdrój, Jelenia Góra, Kołobrzeg, Kraków (Swoszowice), Krynica-Zdrój, Kudowa-Zdrój, Lądek-Zdrój, Muszyna, Nałęczów, Niemcza (Przerzeczyn-Zdrój), Polanica-Zdrój, Połczyn-Zdrój, Rabka-Zdrój, Solina (Polańczyk-Zdrój), Solec-Zdrój, Sopot, Szczawnica, SzczawnoZdrój, Świeradów-Zdrój, Świnoujście, Ustka (urban commune), Ustroń, Uście Gorlickie (Wysowa).

${ }^{2}$ For nine communes data deficiencies have not allowed correlation coefficients to be calculated: Bystrzyca Kłodzka (Długopole-Zdrój), Jedlina-Zdrój, Kamień Pomorski, Konstancin-Jeziorna, Krasnobród, Sękowa (Wapienne), Supraśl, Uniejów and Wieliczka.

\section{BIBLIOGRAPHY}

BORKOWSKI K., GRABIŃSKI T., SEWERYN R., MAZANEK L., GRABIŃSKA E., 2017, Ruch turystyczny w Krakowie w 2016 roku, Małopolska Organizacja Turystyczna, Kraków.

DERCO J., PAVlisinOVA D., 2016, Financial position of medical spas - the case of Slovakia, Tourism Economics, 23(4), pp. 867873, doi: $10.5367 /$ te.2016.0553.

DRYGLAS D., RÓŻYCKI P., 2016, European spa resorts in the perception of non-commercial and commercial patients and tourists: the case study of Poland, E-review of Tourism Research (eRTR), 13(1/2), pp. 382-400.

DRYGlas D., SAlAMAGA M., 2017, Applying destination attribute segmentation to health tourists: A case study of Polish spa resorts, Journal of Travel and Tourism Marketing, 34(4), pp. 503514, doi: 10.1080/10548408.2016.1193102.

DRYGLAS D., RÓŻYCKI P., 2017, Profile of tourists visiting European spa resorts: a case study of Poland, Journal of Policy Research in Tourism, Leisure and Events, pp. 1-20, doi: 10.1080/1940 7963.2017.1297311.
DURYDIWKA M., 2012, Czynniki rozwoju i zróżnicowanie funkcji turystycznej na obszarach wiejskich w Polsce, Wyd. Wydziału Geografii i Studiów Regionalnych Uniwersytetu Warszawskiego, Warszawa.

DZIEDZIC E. (ed.), 2010, Regionalne badania konsumentów ustug turystycznych, Polska Organizacja Turystyczna, Warszawa.

GOŁEMBSKI G., MAJEWSKA J., 2015, Ocena oddziaływania samorządu na rozwój funkcji turystycznej dużego miasta, [in:] G. Gołembski i in. (eds.), Turystyka w badaniach ekonomicznych, Wyd. Naukowe PWN, Warszawa, pp. 41-60.

KOSMACZEWSKA J., 2013, Turystyka jako czynnik rozwoju obszarów wiejskich, Bogucki Wyd. Naukowe, Poznań.

MAJEWSKA J., 2012, Rola samorzadu terytorialnego w ksztattowaniu funkcji turystycznej gminy, Wyd. Uniwersytetu Ekonomicznego w Poznaniu, Poznań.

Romanova G.M., VetTineV A., Dimanche F., 2015, Health and wellness tourism, [in:] F. Dimanche, L. Andrades (eds.), Tourism in Russia: A management handbook, Emerald, pp. 231-287.

STELMACH P., 2017a, Struktura dystrybucji ustug uzdrowiskowych a funkcja uzdrowiskowa gmin. Koncepcja i wstępne wyniki badań, Prace Naukowe Uniwersytetu Ekonomicznego we Wrocławiu, in press.

STELMACH P., 2017b, Trendy dystrybucji usług uzdrowiskowych w gminach województwa podkarpackiego, [in:] B. GierczakKorzeniowska (ed.), Turystyka a rozwój regionalny - szanse, wyzwania, perspektywy, Wyd. Uniwersytetu Rzeszowskiego, Rzeszów, in press.

SZAFRAŃSKA E., WŁODARCZYK B., DZIEDZIC E., 2015, Pomiar wielkości ruchu turystycznego w regionie, [in:] E. Dziedzic (ed.), Badania konsumentów ustug turystycznych w regionach, Polska Ogranizacja Turystyczna, Warszawa.

SZROMEK A.R., 2012a, Funkcja uzdrowiskowa i jej znaczenie w gospodarce gmin uzdrowiskowych, [in:] A. Szromek (ed.), Uzdrowiska i ich funkcja turystyczno-lecznicza, Proksenia, Kraków, pp. 35-57.

SZROMEK A.R., 2012b, Wskaźniki funkcji turystycznej. Koncepcja wskaźnika funkcji turystycznej i uzdrowiskowej, Wyd. Politechniki Śląskiej, Gliwice.

SZROMEK A.R., 2015, Realizacja funkcji uzdrowiskowej w gminach uzdrowiskowych województwa świętokrzyskiego, Zeszyty Naukowe Politechniki Śląskiej, ser. „Organizacja i Zarządzanie", 82, 1940, pp. 289-299.

SZROMEK A.R., ROMANIUK P., HADZIK A., 2016, The privatization of spa companies in Poland - An evaluation of policy assumptions and implementation, Health Policy, 120, pp. 362368.

VRKLJAN S., HENDIJA Z., 2016, Business performance of health tourism service providers in the Republic of Croatia, Acta Clinica Croatica, 55(1), pp. 79-85.

WŁODARCZYK B. (ed.), 2017, Cel i zakres opracowania oraz materiały źródłowe i metody badań, [in:] B. Włodarczyk (ed.), Ruch turystyczny w Łodzi i województwie łódzkim, Instytut Geografii Miast i Turyzmu, Uniwersytet Łódzki, Łódź.

ZMYŚLONY P., 2015, Funkcja turystyczna w procesie internacjonalizacji miast, Proksenia, Kraków.

Article received:

18 June 2017

Accepted:

27 July 2017 